\title{
Genetic transformation of Citrus sinensis with Citrus tristeza virus (CTV) derived sequences and reaction of transgenic lines to CTV infection
}

\author{
F.R. MUNIZ ${ }^{1}$, A.J. DE SOUZA ${ }^{1}$, L.C.L. STIPP ${ }^{2}$, E. SCHINOR ${ }^{1}$, W. FREITAS, Jr. ${ }^{1}$, R. HARAKAVA ${ }^{3}$, \\ D.R. STACH-MACHADO ${ }^{4}$, J.A.M. REZENDE ${ }^{1}$, F.A.A. MOURÃO FILHO ${ }^{1}$ and B.M.J. MENDES ${ }^{2 *}$ \\ Escola Superior de Agricultura "Luiz de Queiroz", Universidade de São Paulo, 13418-900, Piracicaba, SP, Brazil ${ }^{1}$ \\ Centro de Energia Nuclear na Agricultura, Universidade de São Paulo, 13400-970, Piracicaba, SP, Brazil ${ }^{2}$ \\ Instituto Biológico de São Paulo, 04014-002, São Paulo, SP, Brazil ${ }^{3}$ \\ Instituto de Biologia, Universidade Estadual de Campinas, 13083-970, Campinas, SP, Brazil ${ }^{4}$
}

\begin{abstract}
Transgenic Citrus sinensis (L.) Osb. plants, cvs. Valencia and Hamlin, expressing Citrus tristeza virus (CTV) derived sequences were obtained by genetic transformation. The gene constructs were pCTV-CP containing the $25 \mathrm{kDa}$ major capsid protein gene $(C T V-C P), p C T V-d s C P$ containing the same $C T V-C P$ gene in an intron-spliced hairpin construct, and $p C T V$ - $C S$ containing a $559 \mathrm{nt}$ conserved region of the CTV genome. The transgenic lines were identified by PCR and the transgene integration was confirmed by Southern blot. Transgene mRNA could be detected in most transgenic lines containing $p C T V$ - $C P$ or $p C T V$ - $C S$ transgene. The mRNA of $p C T V$ - $d s C P$ transgene was almost undetectable, with very light bands in most analyzed plants. The transgene transcription appears to be closely linked to the type of gene construct. The virus challenge assays reveals that all transgenic lines were infected. However, it was possible to identify propagated clones of transgenic plants of both cultivars studied with a low virus titer, with values similar to the noninoculated plants (negative control). These results suggested that the transgenic plants present some level of resistance to virus replication. The higher number of clones with low virus titer and where mRNA could not be detected or was presented in a very light band was found for $p C T V$ - $d s C P$-derived transgenic lines.
\end{abstract}

Additional key words: disease resistance, hairpin, gene silencing, sweet orange.

Citrus tristeza virus (CTV), the causal agent of the most important viral disease affecting citrus, causes quick decline of most citrus species grafted on sour orange. CTV infection may also causes stem pitting, plant stunting, as well as reduction in fruit yield and quality of some scion cultivars regardless of the rootstock (Bar-Joseph et al. 1989, Domínguez et al. 2000).

Since the first description of citrus genetic transformation, the possibility of obtaining transgenic plants resistant or tolerant to CTV has been evaluated with the use of different viral gene constructs and citrus genotypes (Domínguez et al. 2000). Recently, the studies of RNA-mediated gene silencing and the association of this phenomenon with plant's natural antiviral defense (Waterhouse et al. 2001) have stimulated the investigation of the occurrence of transcriptional (TGS) and post-transcriptional gene silencing (PTGS) in transgenic citrus plants containing transgenes that could influence CTV replication (Fagoaga et al. 2006, Febres et al. 2008). Moreover, it has been found out that gene

Received 9 April 2010, accepted 20 December 2010.

Abbreviations: BAP - 6-benzylaminopurine; CTV - Citrus tristeza virus.

Acknowledgements: The authors acknowledge Fundação de Amparo à Pesquisa do Estado de São Paulo (FAPESP), Conselho Nacional de Desenvolvimento Científico e Tecnológico (CNPq), Coordenação de Aperfeiçoamento de Pessoal de Nível Superior (CAPES), and Fundo de Defesa da Citricultura (Fundecitrus) for research financial support and research fellowships; Sanicitrus Mudas Cítricas (Araras, SP, Brazil) and Horticitrus Mudas Cítricas (Cordeirópolis, SP, Brazil) for kindly providing rootstock material and non-transgenic budwood; Centro APTA Citros Sylvio Moreira (Cordeirópolis, SP, Brazil) for kindly providing seeds of the sweet orange cultivars and certified CTV infected budwood. The first two authors contributed equally to this work.

* Corresponding author; fax: (+55) 193429 4610, e-mail: beatriz.mendes@pq.cnpq.br 
constructs designed to produce self-complementary RNA (hairpin) sequences, which fold into dsRNA structure, are more effective in inducing targeted virus resistance (Waterhouse et al. 2001). This fact has encouraged the use of hairpin gene constructs for CTV resistance in citrus (Batuman et al. 2006, Ananthakrishnan et al. 2007). Although only one citrus transgenic line was identified as resistant to CTV (Febres et al. 2008) so far, some propagated clones have shown to impair CTV virus replication (Fagoaga et al. 2006, Febres et al. 2008) and others have shown a significant delay in virus accumulation and symptom onset (Domínguez et al. 2002, Moreno et al. 2008).

These results have motivated the production of Citrus sinensis cvs. Valencia and Hamlin transgenic lines containing three different gene constructs, which could influence the host resistance to CTV. The transgenic lines have been challenged with the pathogen in order to investigate the efficiency of each gene construct in controlling virus replication.

Citrus sinensis (L.) Osb. cvs. Valencia and Hamlin seeds were extracted from ripe fruits and dried at room temperature $(24 \mathrm{~h})$. In vitro seeds germination and explants preparation were performed according to Tavano et al. (2009).

The CTV $25 \mathrm{kDa}$ major capsid protein gene $(C T V-C P)$ was RT-PCR amplified from total RNA of a CTV infected sweet orange tree. For genetic transformation the explants were incubated with Agrobacterium tumefaciens (Smith and Towns) Conn-EHA105 suspension $\left(5 \times 10^{8} \mathrm{CFU} \mathrm{cm}^{-3}\right.$, $20 \mathrm{~min})$, carrying one of the following binary vectors: $p C T V-C P$ containing the capsid protein gene cloned in sense orientation between the CaMV $35 \mathrm{~S}$ promoter and terminator, $p C T V-d s C P$ containing the same $C T V-C P$ gene in a intron-spliced hairpin construct, and $p C T V-C S$ containing a $559 \mathrm{nt}$ conserved region of the CTV genome, cloned in antisense orientation between CaMV $35 \mathrm{~S}$ promoter and terminator. The explants were blotted dry and transferred to regeneration medium according to Grosser and Gmitter (1990; EME), supplemented with $1.0 \mathrm{mg} \mathrm{dm}^{-3}$ 6-benzylaminopurine (BAP), for a 3-d cocultivation period $\left(24^{\circ} \mathrm{C}\right.$, in the dark). Then, explants were transferred to selection and regeneration medium consisted of EME medium supplemented with $1.0 \mathrm{mg} \mathrm{dm}^{-3}$ BAP, $100 \mathrm{mg} \mathrm{dm}^{-3}$ kanamycin, and $500 \mathrm{mg} \mathrm{dm}^{-3}$ cefotaxime. Cultures were incubated in the dark $\left(27^{\circ} \mathrm{C}\right)$ for approximately 4 weeks and then transferred to $16-\mathrm{h}$ photoperiod (irradiance of $63 \mu \mathrm{mol} \mathrm{m} \mathrm{m}^{-2} \mathrm{~s}^{-1}$, temperature of $\left.27 \pm 1^{\circ} \mathrm{C}\right)$.

Genomic DNA was extracted according to Doyle and Doyle (1991) from leaves of in vitro shoots and evaluated by PCR. The CP gene fragment (684 bp) of $p C T V-C P$ and $p C T V-d s C P$ gene constructs was amplified with the primers 5'-GGGCCCATGGACGACGARACAAAG-3' and 5'-CTCGAGTCAACGTGTGTTRAATTTCC-3' and the reactions were performed under the following conditions: $94{ }^{\circ} \mathrm{C} 3 \mathrm{~min}, 39$ cycles of $94{ }^{\circ} \mathrm{C} 15 \mathrm{~s}, 56{ }^{\circ} \mathrm{C}$
$30 \mathrm{~s}, 72{ }^{\circ} \mathrm{C} 40 \mathrm{~s}$, and final extension at $72{ }^{\circ} \mathrm{C} 5 \mathrm{~min}$. The conserved sequence fragment (559 bp) of $p C T V-C S$ was amplified with the primers 5'-AGAACGAGG TGGCGCATA-3' and 5'-CTTTGGTTCACGCAT ACGTT3' and the reactions were performed under the following conditions: $94{ }^{\circ} \mathrm{C} 2 \mathrm{~min}, 39$ cycles of $94{ }^{\circ} \mathrm{C}$ $30 \mathrm{~s}, 60{ }^{\circ} \mathrm{C} 30 \mathrm{~s}, 72{ }^{\circ} \mathrm{C} 30 \mathrm{~s}$, and a final extension at $72{ }^{\circ} \mathrm{C} 5 \mathrm{~min}$. PCR-positive shoots were carefully excised from the explants and micrografted in vitro onto Carrizo citrange [C. sinensis $\times$ Poncirus trifoliate (L.) Raf] seedlings. Well-developed plants were acclimatized in a greenhouse. The transformation efficiency was expressed as the percentage of PCR-positive plants over to the total number of explants exposed to A. tumefaciens. Genetic transformation was confirmed by Southern blot analysis.

The transgene transcription was studied by reverse transcriptase RT-PCR. Total RNA was extracted from leaves $(200 \mathrm{mg})$ of transgenic lines and a non-transgenic control line. Genomic DNA was removed using $R Q 1$ RNase-free DNase (Promega, Madison, USA) and RNA was quantified using Qubit fluorometer (Invitrogen, Carlsbad, USA). First strand cDNA synthesis was carried out with SuperScript II reverse transcriptase (Invitrogen).

Six to nine transgenic lines containing each gene construct and a non-transgenic control line of each cultivar studied were propagated for pathogen resistance evaluation. Five well-developed buds of each transgenic and non-transgenic line were grafted onto 5-month-old seedlings of Rangpur lime (C. limonia Osb.) rootstock plants. After a 4-month incubation period, when the new shoots were $30-40 \mathrm{~cm}$ long, three plants from each transgenic and control lines were selected for pathogen challenge assays. Each plant was graft-inoculated with two buds collected from a mild strain CTV infected sweet orange cv. Pera (CTV-IAC), at Centro APTA Citros Sylvio Moreira, IAC, Cordeirópolis/SP, Brazil. The inoculation was performed in the rootstock $1-2 \mathrm{~cm}$ below the bud union. After 4 - 5 weeks, virus infection and/or accumulation in leaves of the first flush were monitored by indirect double antibody sandwich enzyme linked immunosorbent assays (DASI-ELISA).

Total proteins were extracted from leaf tissue $(0.4 \mathrm{~g})$ collected from transgenic and non-transgenic inoculated plants (positive control), and from non-transgenic noninoculated plants (negative control) using phosphate buffer saline $\left(2 \mathrm{~cm}^{-3}\right)+$ Tween 20 (0.05\%; PBS-T), supplemented with polyvinylpyrrolidone (2\%). The leaves were randomly collected from different regions of the plants. All DASI-ELISA (Clark et al. 1986, Gamsey and Cambra 1991) were performed in flat bottomed-96 wells plates (Nunc, Rochester, USA), using three wells per sample. Briefly, the plates were coated with $100 \mathrm{~mm}^{-3}$ well $^{-1}$ of \#1006 rabbit polyclonal immunoglobulin in a dilution of 1:1 000 (Baptista et al. 1996) in sodium carbonate buffer (0.05 $\mathrm{M}, \mathrm{pH} 9.6,4{ }^{\circ} \mathrm{C}$, overnight). The wells were washed in PBS-T $(3 \times)$ and incubated with bovine serum albumin (BSA; $\left.2 \%, 1 \mathrm{~h}, 37^{\circ} \mathrm{C}\right)$. After 
washing, the wells were incubated with $100 \mathrm{~mm}^{-3}$ of purified recombinant proteins (CB-22 or CB-104) or plant extracts $\left(2 \mathrm{ng} \mathrm{cm}{ }^{-3}, 4 \mathrm{~h}, 37^{\circ} \mathrm{C}\right)$. After rinsing with PBS-T $(3 \times)$, CTV-IAC strain monoclonal antibodies 30.G.02 (100 mm $\mathrm{mm}^{-3}, 2 \mathrm{ng} \mathrm{cm}$ ), was added to each well $\left(2 \mathrm{~h}, 37^{\circ} \mathrm{C}\right)$. Later, the wells were rinsed again and a 1:30 000 dilution of goat anti-mouse antibody conjugated with alkaline phosphatase $\left(2 \mathrm{~h}, 37^{\circ} \mathrm{C}\right.$, Sigma, St. Louis, USA) was added. Finally, after another PBS-T wash, the reaction was determined by adding $p$-nitro-phenylphosphate (pNPP; $1 \mathrm{mg} \mathrm{cm}^{-3}$ ) in diethanolamine buffer (10\%, pH 9.8, room temperature, $1 \mathrm{~h}$ ). The absorbance (A) was measured at $405 \mathrm{~nm}$ using an Expert PlusMultiplate plate reader (ASYS HITECH, Eugendorf, Austria). A plant was considered infected when the absorbance values (mean of 3 measures) were at least twice those of non-inoculated control plants.

Putative transgenic shoots were identified by PCR. The shoots were in vitro grafted onto Carrizo citrange seedlings and developed into 15,13 , and 16 plants of cv. Valencia containing the $p C T V-C P, p C T V-d s C P$, and $p C T V$-CS transgenes, respectively. For cv. Hamlin 18, 22, and 17 plants were obtained containing the $p C T V-C P$, $p C T V-d s C P$, and $p C T V-C S$ transgenes, respectively. These results correspond to a genetic transformation efficiency of $1.5 \%$ for $p C T V-C P, 1.5 \%$ for $p C T V-d s C P$,

\section{A Valencia}
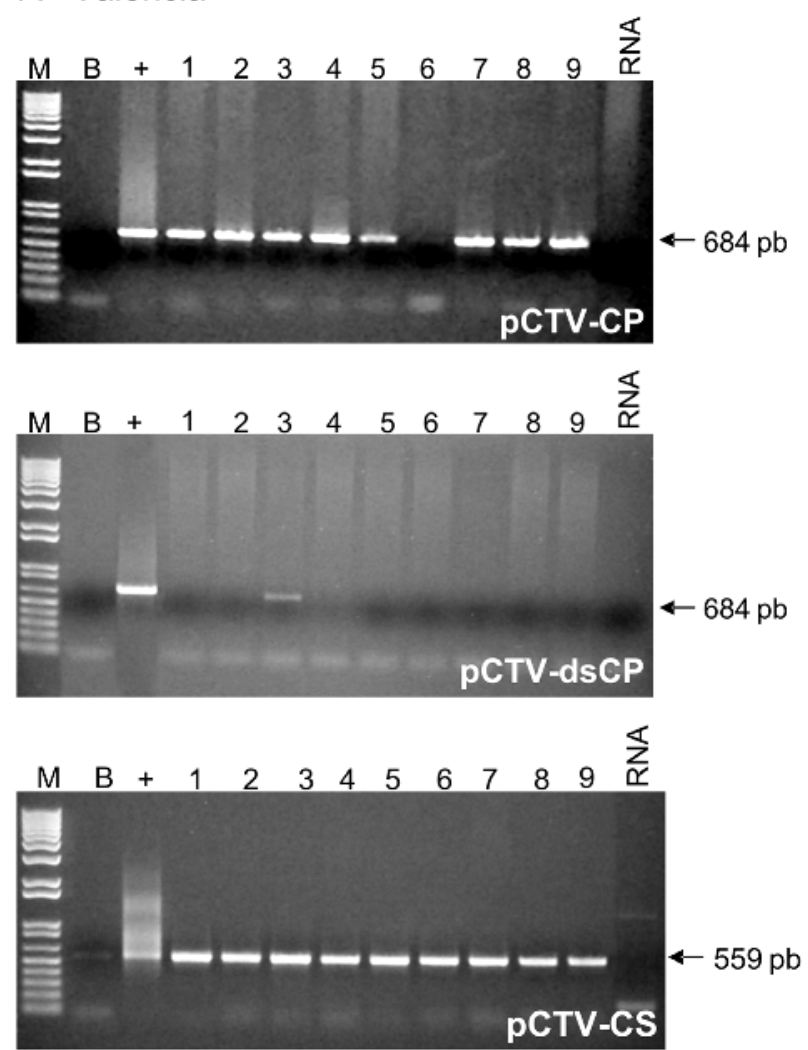

and $2.0 \%$ for $p C T V$ - $C S$ gene construct for $\mathrm{cv}$. Valencia, and $1 \%$ for $p C T V-C P, 2.4 \%$ for $p C T V-d s C P$, and $0.67 \%$ for $p C T V-C S$ gene construct for cv. Hamlin. The plants were acclimatized and cultivated in greenhouse. Genetic transformation was confirmed by Southern blot analyses (data not shown). Most of the transgenic lines displayed $1-2$ integration events. Only the transgenic line 6 of $p C T V-C P$ in $\mathrm{cv}$. Valencia showed 4 integration events. The Southern blot profile indicated that the transgenic lines came from different transformation events.

The transgene expression was investigated by RT-PCR in non-inoculated transgenic lines (Fig. 1). The mRNA accumulation of $p C T V-C P$ transgene was found in 8 out of 9 Valencia and in all 6 Hamlin transgenic lines analyzed. The mRNA of $p C T V-d s C P$ transgene (hairpin) was undetectable in most Valencia transgenic lines evaluated. In fact, only 1 Valencia transgenic line (line 3) showed a very light band. For transgenic lines of Hamlin the mRNA of $p C T V-d s C P$ transgene could be detected in all lines analyzed, however the bands were very light, almost undetectable in some plants (lines 4, 5 and 6). This result is probably related with a lower amount of mRNA in these lines. The mRNA of the $p C T V-C S$ transgene was present in all Valencia and in 8 out of 9 Hamlin transgenic lines analyzed. The transgene

\section{B Hamlin}
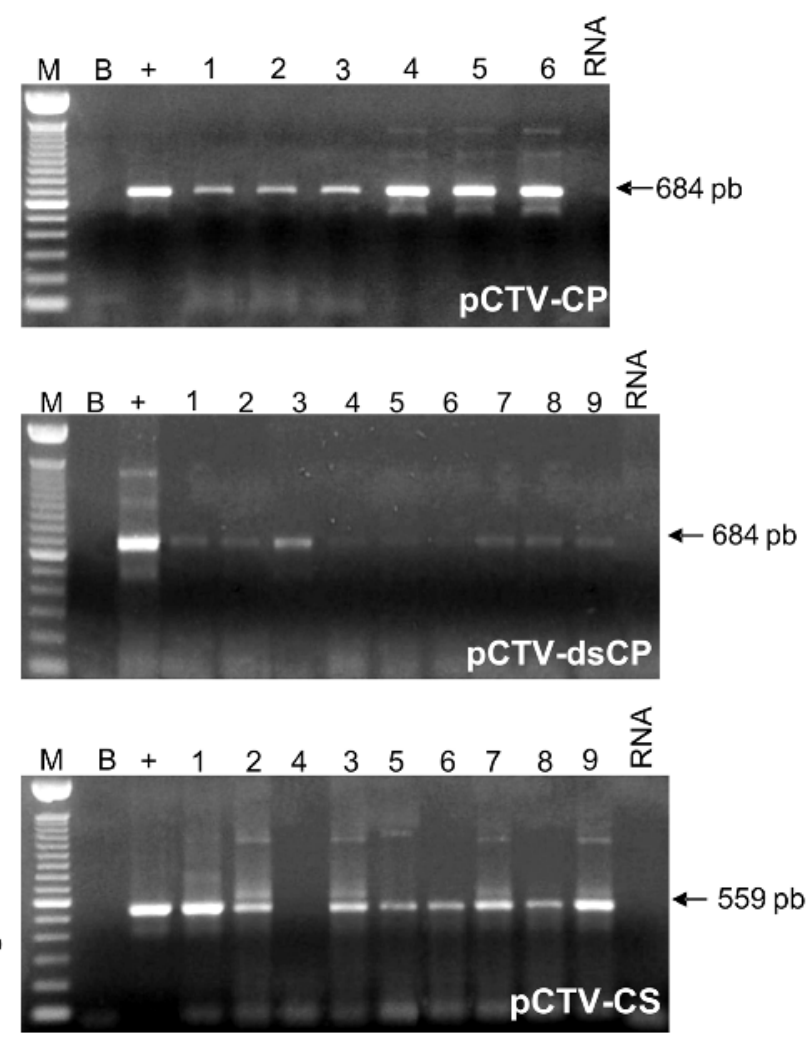

Fig. 1. RT-PCR analyses of $C$. sinensis cvs. Valencia $(A)$ and Hamlin $(B)$. Lanes 1- 9: transgenic lines, +: positive control (consisted of DNA from a transgenic plant); B: blank (water); RNA: RNA sample treated with DNAse. 
transcription appears to be closely linked to the type of gene construct.

Based on DASI-ELISA, all transgenic lines as well as the non-transgenic controls were infected by the mild strain of CTV. The $A_{405 \mathrm{~nm}}$ values ranged from -0.050 to 1.510 for Valencia transgenic lines and from 0.000 to 2.926 for Hamlin transgenic lines. The $\mathrm{A}_{405 \mathrm{~nm}}$ for the nontransgenic positive and negative controls were 1.111 and -0.021 for Valencia and 1.663 and 0.025 for Hamlin. However, it was possible to identify propagated clones of particular transgenic lines in both cultivars studied, with a very low virus titer (Table 1). For Valencia, it was possible to identify 1 clone with low virus titer for transgenic lines 2,3 , and 9 containing the $p C T V$-CP $\left(\mathrm{A}_{405 \mathrm{~nm}}-0.016\right.$ to -0.003$)$, for transgenic lines 1,5 , and 8 containing the $p C T V-d s C P\left(\mathrm{~A}_{405 \mathrm{~nm}}-0.050\right.$ to -0.016$)$, and for transgenic lines 7,8 , and 9 containing the $p C T V$-CS $\left(\mathrm{A}_{405 \mathrm{~nm}}-0.019\right.$ to -0.015$)$. In addition, transgenic line 6 containing $p C T V$-ds $C P$ presented 2 clones with very low

Table 1. Evaluation of CTV replication by DASI-ELISA in Citrus sinensis cvs. Valencia and Hamlin transgenic lines, containing the gene constructs $p C T V-C P, p C T V-d s C P$ and $p C T V-C S . \mathrm{C}^{-}$- negative control (non-transgenic non-inoculated plants); $\mathrm{C}^{+}$- positive control (non-transgenic inoculated plants).

Infected plants/inoculated plants

Lines $\quad p C T V-C P \quad p C T V-d s C P \quad p C T V-C S$ ValenciaHamlin ValenciaHamlin ValenciaHamlin

\begin{tabular}{lllllll}
\hline 1 & $3 / 3$ & $3 / 3$ & $2 / 3$ & $1 / 3$ & $3 / 3$ & $2 / 3$ \\
2 & $2 / 3$ & $3 / 3$ & $3 / 3$ & $3 / 3$ & $3 / 3$ & $2 / 3$ \\
3 & $2 / 3$ & $2 / 3$ & $3 / 3$ & $1 / 3$ & $3 / 3$ & $3 / 3$ \\
4 & $3 / 3$ & $3 / 3$ & $3 / 3$ & $3 / 3$ & $3 / 3$ & $3 / 3$ \\
5 & $3 / 3$ & $2 / 3$ & $2 / 3$ & $3 / 3$ & $3 / 3$ & $3 / 3$ \\
6 & $3 / 3$ & $3 / 3$ & $1 / 3$ & $1 / 3$ & $3 / 3$ & $2 / 3$ \\
7 & $3 / 3$ & - & $3 / 3$ & $1 / 3$ & $2 / 3$ & $3 / 3$ \\
8 & $3 / 3$ & - & $2 / 3$ & $3 / 3$ & $2 / 3$ & $2 / 3$ \\
9 & $2 / 3$ & - & $3 / 3$ & $3 / 3$ & $2 / 3$ & $2 / 3$ \\
$\mathrm{C}^{-}$ & $0 / 3$ & $0 / 3$ & $0 / 3$ & $0 / 3$ & $0 / 3$ & $0 / 3$ \\
$\mathrm{C}^{+}$ & $3 / 3$ & $3 / 3$ & $3 / 3$ & $3 / 3$ & $3 / 3$ & $3 / 3$ \\
\hline
\end{tabular}

\section{References}

Ananthakrishnan, G., Orbović, V., Pasquali, G., Ćalović, M., Grosser, J.W.: Transfer of Citrus tristeza virus (CTV)derived resistance candidate sequences to four grapefruit cultivars through Agrobacterium-mediated genetic transformation. - In Vitro cell. dev. Biol. Plant 43: 593-601, 2007.

Baptista, C.R., Vega, J., Stach-Machado, D.R., Targon, M.L.P.N., Müller, G.W., Machado, M.A.: Método simplificado de purificação do vírus da tristeza dos citros e obtenção de anti-soro de alta especificidade. - Summa Phytopatol. 22: 234-238, 1996. [In Port.]

Bar-Joseph, M., Marcus, R., Lee, R.F.: The continuous challenge of Citrus tristeza virus control. - Annu. Rev. virus titer $\left(\mathrm{A}_{405 \mathrm{~nm}}-0.045\right.$ and -0.028$)$. Considering Hamlin transgenic lines 3 and 5 containing the $p C T V-C P$, and transgenic lines $1,2,6,8$ and 9 containing the $p C T V$-CS only 1 clone was with very low virus titer $\left(\mathrm{A}_{405 \mathrm{~nm}} 0.051\right.$ to 0.268$)$. The transgenic lines $1,3,6$ and 7 containing the $p C T V$-ds $C P$ presented 2 clones with low virus titer $\left(\mathrm{A}_{405 \mathrm{~nm}} 0.000\right.$ to 0.008$)$.

It was not possible to identify any transgenic line, for both cultivars studied, having the 3 propagated clones with low virus titer. However transgenic lines containing the $p C T V$ - $d s C P$ gene construct showed a higher number of propagated clones with low virus titer $\left(\mathrm{A}_{405 \mathrm{~nm}}\right.$ values similar to non-inoculated control) and where mRNA was undetectable or presented in a very light band (Fig. 1, Table 1). This variable response among propagated cloned plants has also been described for $C$. aurantifolial CTV pathosystem (Domínguez et al. 2002) with 25 - $33 \%$ of clonal plants from the same transgenic line not developing symptoms and virus replication not being detected by DAS-ELISA. Fagoaga et al. (2006) and Febres et al. (2008) also reported that propagations from the same transgenic line showed different responses to CTV in C. aurantifolia and C. paradise. Such response is not fully understood, but it may be related to either characteristics of the inoculation process, such as virus dosing or different viral populations (Domínguez et al. 2002), or to other abiotic factors that may interfere with the silencing pathway (Febres et al. 2008, Moreno et al. 2008). Our results indicate that the transgenic lines containing $p C T V-d s C P$ gene construct showed the highest number of propagated clones exhibiting resistance to virus replication, based on the very low mean absorbance values obtained in DASI-ELISA.

To the best of our knowledge, this is the first report of pathogen derived resistance (Sanford and Johnston 1985) use in $C$. sinensis/CTV pathosystem. Efforts are underway in order to challenge the transgenic plants with a more severe CTV strain by vector (Toxoptera citricida Kirk.) inoculation, which is a natural way of virus dissemination. The resistant clones will also be checked for siRNA accumulation.
Phytopathol. 27: 291-316, 1989.

Batuman, O., Mawassi, M., Bar-Joseph, M.: Transgenes consisting of a dsRNA of an RNAi suppressor plus the 3' UTR provide resistance to Citrus tristeza virus sequences in Nicotiana benthamiana but not in citrus. - Virus Genes 33: 319-327, 2006.

Clark, M.F., Lister, R.M., Bar-Joseph, M.: ELISA techniques. Method. Enzymol. 118: 742-766, 1986.

Domínguez, A., Guerri, J., Cambra, M., Navarro, L., Moreno, P., Peña, L.: Efficient production of transgenic citrus plants expressing the coat protein gene of Citrus tristeza virus. Plant Cell Rep. 19: 427-433, 2000.

Domínguez, A., Mendoza, A.H., Guerri, J., Cambra, M., 
Navarro, L., Moreno, P., Peña, L.: Pathogen-derived resistance to Citrus tristeza virus (CTV) in transgenic mexican lime (Citrus aurantifolia (Christ.) Swing.) plants expressing its $p 25$ coat protein gene. - Mol. Breed. 10: 1-10, 2002.

Doyle, J.J., Doyle, J.L.: Isolation of plant DNA from fresh tissue. - Focus 1: 13-15, 1991.

Fagoaga, C., López, C., Mendoza, A.H., Moreno, P., Navarro, L., Flores, R., Peña, L.: Post-transcriptional gene silencing of the p23 silencing suppressor of Citrus tristeza virus confers resistance to the virus in transgenic Mexican lime. Plant mol. Biol. 60: 153-165, 2006.

Febres, V.J., Lee, R.F., Moore, G.A.: Transgenic resistance to Citrus tristeza virus in grapefruit. - Plant Cell Rep. 27: 93104, 2008.

Gamsey, S.M., Cambra, M.: Enzyme linked immunosorbent assay for citrus pathogens. - In: Roistacher, C.N. (ed.): Graft-Transmissible Diseases of Citrus: Handbook for
Detection and Diagnosis. Pp. 193-216. IOCV FAO, Rome 1991.

Grosser, J.W., Gmitter, F.G.: Protoplast fusion and citrus improvement. - Plant Breed. Rev. 8: 339-374, 1990.

Moreno, P., Ambrós, S., Albiach-Martí, M.R., Guerri, J., Peña, L.: Citrus tristeza virus: a pathogen that changed the course of the citrus industry. - Mol. Plant Pathol. 9: 251-268, 2008.

Sanford, J.C., Johnston, S.A.: The concept of parasite-derived resistance-deriving resistance genes from the parasite's own genoma. - J. theor. Biol. 113: 395-405, 1985.

Tavano, E.C.R., Stipp, L.C.L., Muniz, F.R., Mourão Filho, F.A.A., Mendes, B.M.J.: In vitro organogenesis of Citrus volkameriana and Citrus aurantium. - Biol. Plant. 53: 395399, 2009.

Waterhouse, P.M., Wang, M.B., Lough, T.: Gene silencing as an adaptative defence against viruses. - Nature 411: 834842, 2001. 